\title{
Properties of the urban watercourse composition under anthropogenic load
}

\author{
Viktor Denisov ${ }^{1 *}$, Ekaterina Bondarenko ${ }^{1}$, and Alexander Scherbakov ${ }^{2}$ \\ ${ }^{1}$ Peter the Great St. Petersburg Polytechnic University, 29, Polytechnic st., St. Petersburg, 195251, \\ Russia \\ ${ }^{2}$ Saint Petersburg State University of Architecture and Civil Engineering, Vtoraya Krasnoarmeiskaya \\ street, 4, Saint Petersburg, 190005, Russia
}

\begin{abstract}
The anthropogenic impact on urban rivers is very significant. Industrial enterprises, municipal, and agricultural organizations discharge wastewater directly into the rivers. In the samples of the studied water, certain properties were found. The water in the river is cloudy, brown in color, and in some places has a sharp smell. Extraneous impurities and foam were detected in water. Moreover, various chemicals were found, which are not characteristic to natural waters. The analyzed water is highly polluted as shown by the following chemical indicators, which reported results higher than the Maximum Allowable Concentration: $\mathrm{Fe}$ concentration is 24 times higher than standard, $\mathrm{Cu}$ is 5 times higher, $\mathrm{Mn}$ is 6 times higher, $\mathrm{Al}$ is 366 times higher, $\mathrm{Hg}$ is 3 times higher, $\mathrm{Zn}$ is 4 times higher, $\mathrm{NO} 2$ is 2.5 times higher, hydrocarbon pollution is 2.8 times higher, NH4 is 1.9 times higher. Therefore, it is necessary to immediately develop effective methods for monitoring the state of the watercourse, both economic and energetic. To save the sustainable development of the natural system.
\end{abstract}

\section{Introduction}

Russia is very rich in water resources. It has a huge river network in which watercourses that are $5-8 \mathrm{~km}$ long make up $76 \%$ of the total number of rivers. These rivers are called small rivers. Every year, surface waters become more polluted. Pollution is a big environmental problem. Rivers have always been a source of fresh water. However, recently they began to transport wastes. Industrial enterprises, municipal, and agricultural organizations discharge wastewater directly into the rivers. The protection of water sources from pollution and their rational use determine the conditions in which humans will live tomorrow.

The problem of developing effective methods for monitoring surrounding environmental conditions is now very significant, since the increasing level of pollution negatively affects the human ecology. Due to the significant total length of small rivers and their secondary economic importance, systematic monitoring of small watercourses is usually neglected [1].

\footnotetext{
*Corresponding author: vikden.99@mail.ru
} 
St. Petersburg is rich in water surfaces, which suffer from serious anthropogenic load. The main watercourse of the city is the Neva River, whic consists also the only source of water supply for St. Petersburg. Pollutants from numerous enterprises, municipal and agricultural organizations located along the banks of Neva fall into it and its tributaries. The Okhta River, with its tributary - the Okkervil River, forms the largest right tributary of the Neva River [2,3]. Over the past decades, its water have been extremely polluted. And this pollution is found to be both complex and steady [4]. The cause of pollution is wastewaters entering the river sometimes without any treatment $[5,6]$. The Okkervil River flows through districts of industrial enterprises, and the flow of household sewage water is also carried into its channel, which causes severe pollution of its water. Moreover, its coast is experiencing erosion, which causes the surrounding houses to begin to "slide" to the pond.

Nowadays, human needs for water for communal needs are greatly increasing [7]. The volume of water consumed for these purposes depends on the region and the standard of living, ranging from 3 to 700 liters per person. From the analysis of water use over the past 5-6 decades, it follows that the annual increase in irrevocable water consumption is $4-5 \%$. [8]. Predictive calculations show that while maintaining such rates of consumption and taking into account population growth and production volumes, by 2100 , mankind can exhaust all fresh water reserves [9]. Therefore, constant monitoring of the state of water bodies is necessary. As well as solving problems aimed at reducing the anthropogenic impact on water quality in rivers, health and life of the population is critically required.

\section{Materials and Methods}

\subsection{Characteristic of water source}

The Okkervil River is a river in Leningrad Oblast and the eastern part of the city of Saint Petersburg, Russia. It is the largest left tributary of the Okhta River. It is 18 kilometres long and 1.5 to 25 metres wide. The riverbed over a considerable extent is silty, rarely rocky. On the banks, there are mixed coniferous forests alternated with fields and meadows. The river is shallow, around 1 meter deep $[10,11]$.

\subsection{Sampling sites are}

Located upstream the monitoring is a river in Leningrad Oblast and the eastern part of the city of Saint Petersburg, Russia. Samples were taken from Okkervil River. Samples were collected at one day. At the same day they were taken to the laboratory and stored at $+4{ }^{\circ} \mathrm{C}$ in vertical position. The upper part of water was analyzed. No filtration was done. They are shown at Figure 1. 


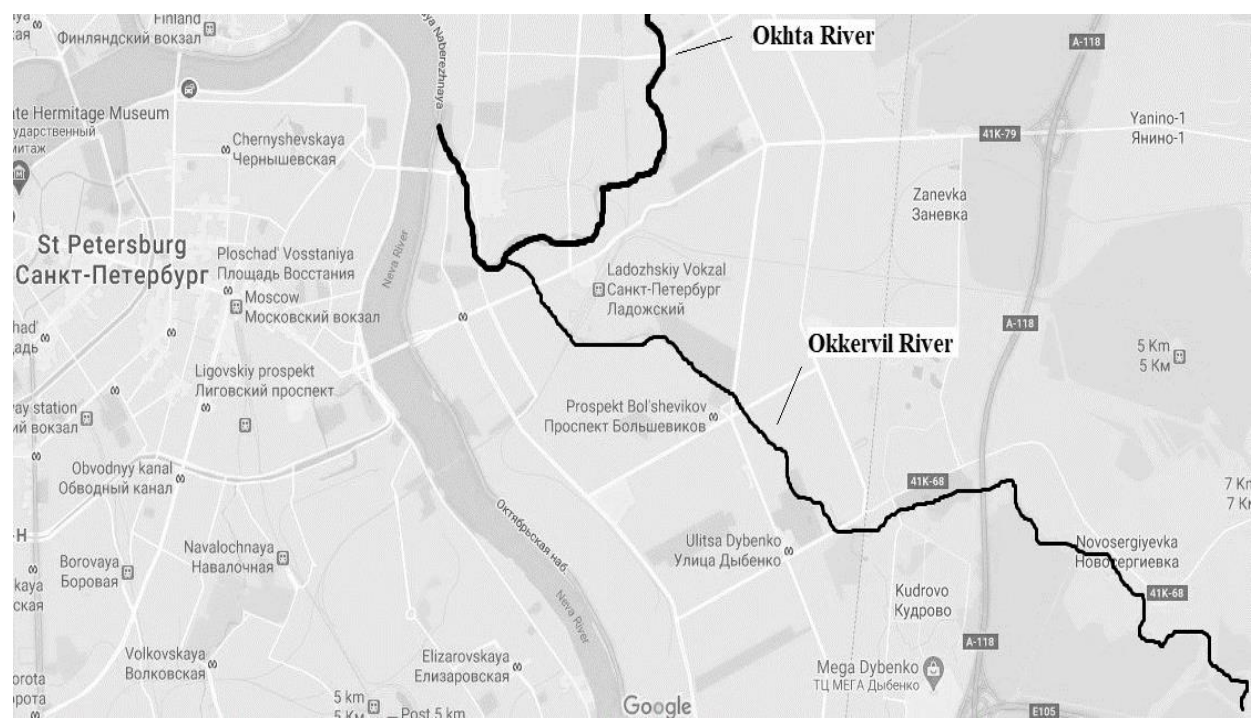

Fig. 1. The Okhta River and the Okkervil River are located in Leningrad Oblast in the eastern part of the city of Saint Petersburg, Russia.

\subsection{Water analysis}

Water analysis was carried out to measure basic chemical, optical and physical indicators. Appropriate methods and techniques were used [12, 13].

Organoleptic indicators. Organoleptic assessment reports both direct and indirect information about the composition of water. Moreover, it can be carried out quickly and without any instruments. Organoleptic characteristics include: colour of water, turbidity (transparency) of water, smell, foaminess [12].

Water colour index. The colour of water varies with the ambient conditions in which that water is present. Dissolved elements or suspended impurities may give water a different color. Color research is a quick and easy way often reflects the amount of organic material in the water, although certain inorganic components like iron or manganese can also impart color. Natural water is characterized by the presence of humic substances and complex compounds of iron. The color of water can be determined by the properties and composition of the riverbed of the water body, the nature of the aquatic vegetation, the soils adjacent to the water body, the presence of swamps and peat bogs in the water body, etc. $[13,14]$. In water, green can indicate copper leaching from copper plumbing and can also represent algae growth. Blue can also indicate copper, or might be caused by syphoning of industrial cleaners. Reds can be signs of rust from iron pipes or airborne. Black water can indicate growth of sulfur-reducing bacteria.

Turbidity (transparency) of water. Turbidity of the water is caused by the content of finely dispersed impurities suspended in it — insoluble or colloidal particles of various origins.

Smell. The odor of water is caused by the presence of volatile substances in it, which poor into the water naturally or with wastewater. Typically, the smell is determined at normal $\left(20^{\circ} \mathrm{C}\right)$ and at elevated $\left(60^{\circ} \mathrm{C}\right)$ water temperature. Odor by nature is divided into two groups: natural origin and artificial origin. Odor intensity is rated on a 5-point scale.

Foaminess is the ability of water to retain artificially created foam. This indicator can be used for a qualitative assessment of the presence of such substances as detergents (surfactants) of natural and artificial origin, etc. Foaminess is determined mainly in the 
analysis of waste and polluted natural waters [12].

Chemical Indicators of Water Quality. The hydrogen index $(p H)$ is the negative logarithm of the concentration of hydrogen ions in the solution. The $\mathrm{pH}$ of natural water is determined, as a rule, by the ratio of the concentrations of bicarbonate anions and free CO. A lower $\mathrm{pH}$ value is characteristic of swamp waters due to the high content of humic and other natural acids.

Nitrates. Nitrates are salts of the nitric acid and are usually present in water. The increased nitrate content in water can serve as an indicator of the pollution of a water body as a result of the spread of fecal or chemical pollution (agricultural, industrial) [15].

Ammonium. Ammonium cations are the product of microbiological decomposition of animal and plant proteins. There are two main sources of environmental pollution by ammonium compounds. Ammonium compounds in large quantities are part of mineral and organic fertilizers, the excessive and improper use of which leads to the subsequent pollution of water bodies. In addition, ammonium compounds are present in significant quantities in sewage (feces) [16].

Iron. One of the most common elements in nature. It is a vital trace element for living organisms and plants.

\section{Results}

Parameters of Water Samples. When determining the turbidity of the water, the presence of a large sediment was detected after the water was settled. [17].

When determining the odor of water, we can say that the it is putrid, of natural origin

After determining the foaminess of the water, it was found that near the bank on the surface of the water you foam and impurities can be found, which indicates the ecological damage of the water body.

Processing of the results according to organoleptic indicators is presented in table 1.

Table 1. Results of Organoleptic Indicators

\begin{tabular}{|c|c|}
\hline Characteristics & Value \\
\hline Smell & putrid \\
\hline Colour & intense yellow \\
\hline Turbidity & cloudy \\
\hline
\end{tabular}

When determining the $\mathrm{pH}$ in the river, it was found to be equal to 6 and 7 . We can conclude that the average $\mathrm{pH}$ in the Okkervil River is 6.5.

As a result of the data on the concentration of chemical elements in the water of the Okkerville River and their comparison with MAC, certain properties were revealed. (Presented in table 2).

Table 2. Results of Chemical Indicators

\begin{tabular}{|c|c|c|c|}
\hline target value & $\begin{array}{c}\text { concentration } \\
{[\mathrm{mg} / \mathrm{L}]}\end{array}$ & $\begin{array}{c}\mathrm{MAC} \\
{[\mathrm{mg} / \mathrm{L}]}\end{array}$ & divergence \\
\hline $\mathrm{NO} 3$ & 0,41 & 40 & 0,01 \\
\hline $\mathrm{NO} 2$ & 0,2 & 0,08 & 2,5 \\
\hline $\mathrm{Mn}$ & 0,06 & 0,01 & 6,0 \\
\hline $\mathrm{Cu}$ & 0,005 & 0,001 & 5,0 \\
\hline $\mathrm{Hg}$ & 0,00003 & 0,00001 & 3,0 \\
\hline $\mathrm{Zn}$ & 0,04 & 0,01 & 4,0 \\
\hline $\mathrm{Fe}$ & 2,4 & 0,1 & 24,0 \\
\hline $\mathrm{NH} 4^{+}$ & 0,76 & 0,4 & 1,9 \\
\hline Hydrocarbons & 0,14 & 0,05 & 2,8 \\
\hline
\end{tabular}




\section{Pollution}

It can be seen that the concentration of NO3 is normal, this can be explained by the lack of agricultural activity along the banks of the Okkervil River. The concentration of NO2 exceeds the norm by 2.5 times, $\mathrm{NH}^{+}$by 1.9 times, which may indicate the ingress of household and household-fecal effluents into the river, the concentration of $\mathrm{Mn}$ is 6 times higher, the concentration of $\mathrm{Cu}$ exceeds TMAC by 5 times, the concentration of $\mathrm{Hg}$ by 3 times. Hydrocarbons Pollution reported a 2.8 times excess was reported. This can be explained by the fact that part of the riverbed passes near roads. The Fe concentration is exceeded by 24 times, which is most likely due to industrial enterprises located along the banks of the river. A high concentration of iron can be explained either by its increased content in swamp waters, however, this is not typical for Okkervil river, which means it gets into the water body with sewage from industrial enterprises located in the city. The increased ammonium content in surface waters is usually a sign of fecal pollution.

\section{Discussion}

The presence of finely dispersed impurities in the water showed that the water in the river is cloudy.

Assessing the intensity of the odor reprted - 3 degrees, and the fact that the smell is easily noticed.

In terms of $\mathrm{pH}$, the water in the Okkervil River complies with the standards and can be applicable for household, cultural and domestic use [17].

As a result of studying the concentration of chemical elements in the water of the Okkervil River, a significant impact of anthropogenic load from industrial enterprises, the drain of household wastewater from municipal and agricultural organizations was revealed. Contaminating discharges and runoff from roads are clearly visible.

According to the data obtained, the river can be characterized as a water body with water of quality class 4 [15].

\section{Conclusions}

The anthropogenic impact on the river is very significant. According to organoleptic indicators, the water in the river is cloudy, brown, and has a sharp smell in certain places. The presence of impurities and foam was detected.

$\mathrm{PH}$ ranges from 5 to 7.5. The results of the study showed that the water of the Okkervil River contains various chemicals that are not characteristic to natural waters. According to the following chemical indicators, the river water is highly polluted: iron content $(\mathrm{Fe})$ exceeds MAC by almost 24 times, copper $(\mathrm{Cu})$ by 5 times, manganese $(\mathrm{Mn})$ by 6 times, aluminium ( $\mathrm{Al})$ by 366 times, mercury $(\mathrm{Hg})$ by 3 times, and zinc $(\mathrm{Zn})$ by 4 times, hydrocarbons by 2.8 times.

Therefore, it is necessary to immediately create effective methods for monitoring the state of the watercourse, both economic and energetic. To maintain the sustainable development of the natural system.

\section{References}

1. Observations and work on large and medium rivers. 3 (2017)

2. A.G. Murav'ev. Guidelines for determining water quality indicators using field methods. 3 (2009) 
3. Kh.V. Il'ina, N.M. Gavrilova et al. Magazine of Civil Engineering, 8, 241-254 (2017) DOI: 10.18720/MCE.76.21

4. M.J. Andrianova, E.A. Bondarenko et al. Workshop on Environmental, Energy and Structural Monitoring Systems, Proceedings, 198-202 (2014)

5. A.S. Bogolyubov. Methods of hydrological research: measurement and description of rivers. 2006

6. Bogolyubov A. S. Metody issledovanij zoobentosa i ocenki ekologicheskogo sostoyaniya vodoemo. 2007

7. N.I. Vatin, M.A. Grekov et al. Water supply and sanitary equipment, 1, 58-65 (2017)

8. F.V. Karmazinov. Wastewater disposal and treatment, 668

9. A. Korsakov, S. Filin, S. Galyuzhin et al. Textbook and Workshop STR, Ecology, 5 (2019)

10. Okhta River. 2019 (Access date: 13.02.2020) URL: http://www.saintpetersburg.com/rivers-and-canals/okhta-river/.

11. Assessment of the ecological status and key problems of the river basin 2, 141 (2015) (Access date: 13.02.2020) URL: www.nordwest-water.ru/activities/ndv/ scheme-ofcomplex-use-andprotection-of-water-bodies-in-the-basin-of-the-river-neva/

12. E. I. Sarvira. The collection of works of the winners of the Republican competition of works of a research nature (conference). 2015

13. GOST 3351-74 Drinking water.

14. Surface water resources of the USSR. 2(3), 959 (1972)

15. GN 2.1.5.1315-03 Predelno dopustimyye kontsentratsii (PDK) khimicheskikh veshchestv v vode vodnykh obyektov khozyaystvenno-pityevogo I kulturno-bytovogo vodopolzovaniya [Maximal allowable concentrations of chemical substances in waters of water objects for economic-drinking and cultural-household use]. (in Russian).

16. Hygienic requirements for surface waters protection. Sanitary norms and rules in Russian. SanPiN 2.1.5.980-00

17. Report on ecological situation in Saint-Petersburg in 2015. 168 (2016) (Access date: 13.02.2020) URL: www.infoeco.ru/assets/files/Doklad/doklad_2015.pdf 